\title{
The European Regional Development Fund and Island Regions: An Evaluation of the 2000-06 and 2007-13 Programs
}

Harvey W. Armstrong

University of Sheffield, United Kingdom

h.armstrong@sheffield.ac.uk

Benito Giordano

Aide à la Décision Économique

Louvain-la-Neuve, Belgium

benito.giordano@ade.eu

Thanasis Kizos

Department of Geography, University of the Aegean, Mytilini, Greece

akizos@aegean.gr

Calum Macleod

Sustainable Development Consultant and Researcher

Bridge of Allan, United Kingdom

calum.macleod.cml@gmail.com

Lise Smed Olsen

Nordregio, Stockholm, Sweden

lise.smed.olsen@nordregio.se

Ioannis Spilanis

Laboratory of Local and Island Development, University of the Aegean, Mytilini, Greece ispil@aegean.gr

ABSTRACT: This paper presents results from a regional policy evaluation study conducted for the European Commission. The study examined the impact of the European Regional Development Fund and Cohesion Fund on EU regions with 'specific geographical characteristics', namely islands, mountain regions and sparsely populated areas. These types of regions have been attracting increasing EU regional policy attention and their economic development is considered important in helping the EU to attain its important 'territorial cohesion' objective. The focus of this paper is on the island regions. Evaluation of island regions in their own right has not been undertaken before by the EU. The study focuses on the 2000-06 and (still on-going) 2007-13 EU regional policy programs. The paper presents the methodology adopted by the study before turning to the main findings concerning the types of policy initiatives adopted in the island regions, and the appropriateness of the policies used for the economic situation faced by the islands. The islands encompassed by the study are all normal sub-national regions of EU member states. Islands with an unusual degree of administrative autonomy (e.g. the Outermost Regions) were excluded.

Keywords: European Union; evaluation; island regions; policy initiatives; regional policy

C 2012, Institute of Island Studies, University of Prince Edward Island, Canada 


\section{H. W. Armstrong et al.}

\section{Introduction}

Interest on how European Union (EU) regional policy can be best brought to bear in islands has been growing in recent years. This interest is likely to continue to grow because the performance of regions with specific geographical features is considered to be an important element in achieving the EU's key long term regional policy objective of territorial cohesion (European Commission, 2006).

While the focus on islands is relatively new, the EU has a long history of devising distinctive policies for regions with specific geographical features. Special assistance for the Outermost Regions (ORs - the Azores Islands and Madeira of Portugal, the Canary Islands of Spain, and the French overseas departments of Guadeloupe, Martinique, Réunion and recently Mayotte all islands - and Guyana) has been in place for decades (European Commission, 2012a). The specific 'geographical feature' which triggered the help for the ORs is remoteness from the EU market. The other type of 'specific geographical feature' region which has attracted more recent special EU intervention has been sparsely populated areas (SPAs). The EU accession of Austria, Finland and Sweden in 1995 resulted in SPAs being accorded special status within EU regional policy (European Commission, 2006), and they have enjoyed this ever since.

This paper presents results from a recent study undertaken for the European Commission (Aide à la Décision Économique - ADE, 2012). The study was an evaluation of the 2000-06 and 2007-13 European Regional Development Fund (ERDF) programs as they have been applied in regions with 'specific geographical features': namely islands, mountain regions and sparsely populated areas. The paper focuses on the island regions. It begins with a brief review of the methodology adopted for the study. The key results for the island regions selected for evaluation are then presented. The Conclusion draws out the main findings and summarizes key similarities and differences between the island regions and the other mountain and SPA regions analysed.

\section{Evaluation Methodology and Selection of the Case Study Regions}

The evaluation adopted a case study methodology. Case study evaluation is one of a suite of evaluation methods recommended by the European Commission (European Commission, $2012 b$ ), and is principally a qualitative evaluation methodology. There are two key advantages to using a case study methodology for island regions:

(a) Existing quantitative data sets (e.g. Eurostat's harmonized statistics) are extremely deficient when it comes to islands. This makes modern quantitative counterfactual impact evaluation almost impossible without very expensive surveys (Martini, 2009). Just how hampered researchers are in seeking to undertake cross-island statistical analysis is vividly shown by those studies which have been attempted. For example, a Planistat Europe (2006) study was able to analyse only 19 of the 286 EU islands with over 50 inhabitants. Moncada et al. (2010) were able to analyses only 28 of 5,116 islands in 28 European countries. An ESPON (2011) study was able to analyse only 31 of 362 inhabited EU27 islands with populations over 50 persons. These 31 islands comprise those EU statistical regions "for which some common basic data are available" (ESPON, 2011, p.5). The important study by Monfort (2009) was able to analyse only 56 islands. These comprise the set of EU statistical regions made up wholly of islands. Extracting data for individual islands from large harmonized data sets such as Eurostat is extremely difficult for three reasons: (i) many of the islands are so small that researchers must use 
data from only the most highly geographically disaggregated parts of the data-base. At these levels, the data is fragmentary and often simply non-existent for key variables; (ii) at broader levels of geographical aggregation the islands are frequently grouped in with parts of the mainland littoral, making it impossible to extract data for the island part of the regions; and (iii) at higher levels of geographical aggregation data are often only available for groups of islands and not individual islands.

(b) The case study approach offers a better chance of overcoming an important problem faced by quantitative evaluations of ERDF programs. These programs are delivered through multi-stakeholder partnerships, involving different national, regional and local organizations. Case studies are arguably better than econometric methods at disentangling the effects of different partners and funding streams. This is because the case study technique "draws on a multitude of perspectives..... or derives from multiple accounts of different actors in the setting ... Case studies are information rich ... The defining feature of the case study is that it is information rich" (European Commission, 2012b, Evalsed Sourcebook: Methods and Techniques: Case Studies Section). This advantage of the case study approach is particularly valuable for those types of policies which involve many different actors and partners, such as innovation policies (Technopolis Group, 2012) or local and community level policies (Instituto per la Ricerca Sociale, 2011). Policy interventions in island economies also involve a wide array of economic and social stakeholders and hence are also prime candidates for a case study methodology. On the downside, a problem faced by case study methods is that, because they are so costly (in time and money) to undertake, it is difficult to generalize from just a few cases to a full set of regions. There has been a lively debate concerning how generalizable case study evaluations are (Flyvbjerg, 2006; Koenig, 2009). This inherent weakness means that great care must be taken in the selection of the case study regions.

In this study, a two-stage procedure was adopted. At the first stage of the study, a set of 15 NUTS2 regions with 'specific geographical features' were chosen. These were subject to a broad brush analysis, using statistical information and a review of previous evaluations and studies of the regions. This broad overview of 15 regions formed the basis of a second stage at which six regions (at NUTS3 or lower) were selected for in-depth analysis. The numbers of case study regions at each stage were pre-set by the European Commission's terms of reference and were determined by the available financial resources for the evaluation study. The NUTS regions are those based on the EU's standard nomenclature for regions for statistical data collection. The hierarchy of regions runs from NUTS0 (the Member States) down to NUTS5 at a very local level. An unfortunate feature of NUTS2 regions is that most tend to group islands with parts of the mainland littoral. This makes the NUTS2 regions peculiarly unhelpful concepts for studying islands.

The criteria for selection of the 15 regions for the initial, 'broad brush' overview were designed to produce as representative a group of regions as possible across the three categories of region (i.e. island regions, mountain regions and sparsely populated regions). Additional criteria for selection were: (a) the list should include both Objective 1 and Objective 2 regions, (b) at this first stage should be NUTS2 regions to maximize data availability, (c) the list should include at least one region from each member state specified by the European Commission in its tender specifications, (d) should preferably comprise NUTS2 regions encompassing several NUTS3 


\section{H. W. Armstrong et al.}

regions within them (to maximize choice at the second stage), and (e) should take into account likely data availability at NUTS3 level (to assist stage 2 in-depth analysis). In practice, the precise selection of the 15 initially selected regions and the six in-depth case study regions was the result of discussions with the European Commission.

Of the 15 initially selected regions, six were wholly or partially island regions (Balearic Islands, Corse, Sicilia, Voreio Aigaio, Hovedstaden - including Bornholm, and the Scottish Highlands \& Islands - H\&I). As noted above, from these, six regions were selected for indepth analysis (at NUTS3 level or lower). These comprised Cuenca (within Castilla la Mancha in Spain); Norrbotten (within Övre Norrland in Sweden); Lesvos (within Voreio Aigaio in Greece); Bornholm (within Hovedstaden in Denmark); Ardèche (within Rhône-Alpes in France); and the Western Isles (within the H\&I region of the UK). Three of these are island regions: Bornholm, Lesvos and the Western Isles.

There has been a long debate on how mountain regions, islands and SPAs should be defined (e.g. Gløersen et al., 2006; Planistat Europe, 2006; Monfort, 2009). The EU has developed its own particular definitions (Monfort, 2009). Mountain regions are defined using a combination of measures of topography (altitude and slopes), the dominant climatic condition (i.e. contrasts in temperature) and land use (i.e. forests, moorland). SPAs are defined using simple population density measures. Islands are defined using a combination of minimum population size and area, minimum distance from the mainland, the absence of a fixed link to the mainland and must not contain an EU member state capital, except Malta and Cyprus (Monfort, 2009).

The study drew upon a combination of research techniques. These included some (limited) cross-EU analysis of regional statistics, an extensive literature review, a review of policy and previous evaluation documents, and an intensive program of interviews and focus groups in each of the six in-depth case study regions (conducted in the second half of 2011). Interviewees and focus group members were selected from amongst the key stakeholders engaged in the programs using two approaches: (a) key managers of the programs themselves were pre-selected and interviewed, followed by (b) a 'snowball' approach to identify and interview other key stakeholders. By 'key' is meant those engaged in the main policy interventions, together with those best informed of how the programs have evolved since 2000 (an important criterion give staff turnover across the two program periods). The full lists of interviewees can be found in annexes to the case study reports and included private, public and voluntary sector stakeholders. Presentation of the results was done using a narrative format, as is appropriate with the case study evaluation methodology (Constantino \& Greene, 2003; Yin, 1981).

Finally, it should be noted that the various regions with 'specific geographical features' do not comprise a mutually exclusive classification. Indeed, many EU islands are also mountainous and/or sparsely populated. Figure 1 shows the three in-depth island case study regions which are the focus of this paper. The Western Isles are both an island region and also a SPA. Part of the region is also mountainous. Lesvos is both an island and mountainous. Only Bornholm is solely an island region. 


\section{Figure 1: Location of the three case study islands and their NUTS2 regions}

Location of Voreio Aigaio

(Source: Eurostat)

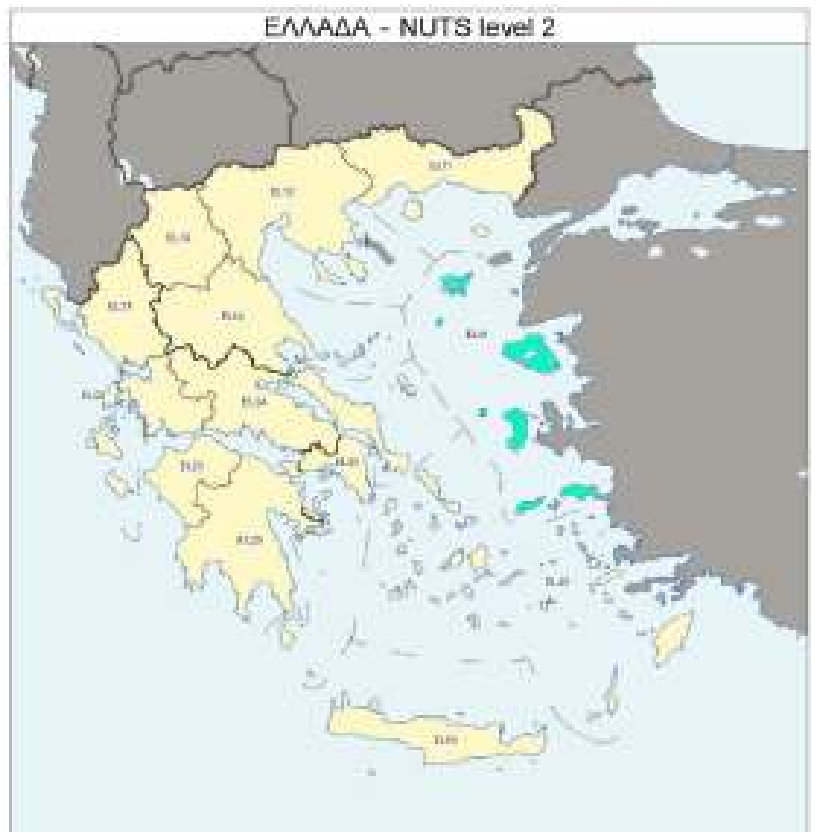

Location of Hovedstaden

(the Copenhagen capital region,

to which Bornholm belongs adminstratively)

(Source: Eurostat)

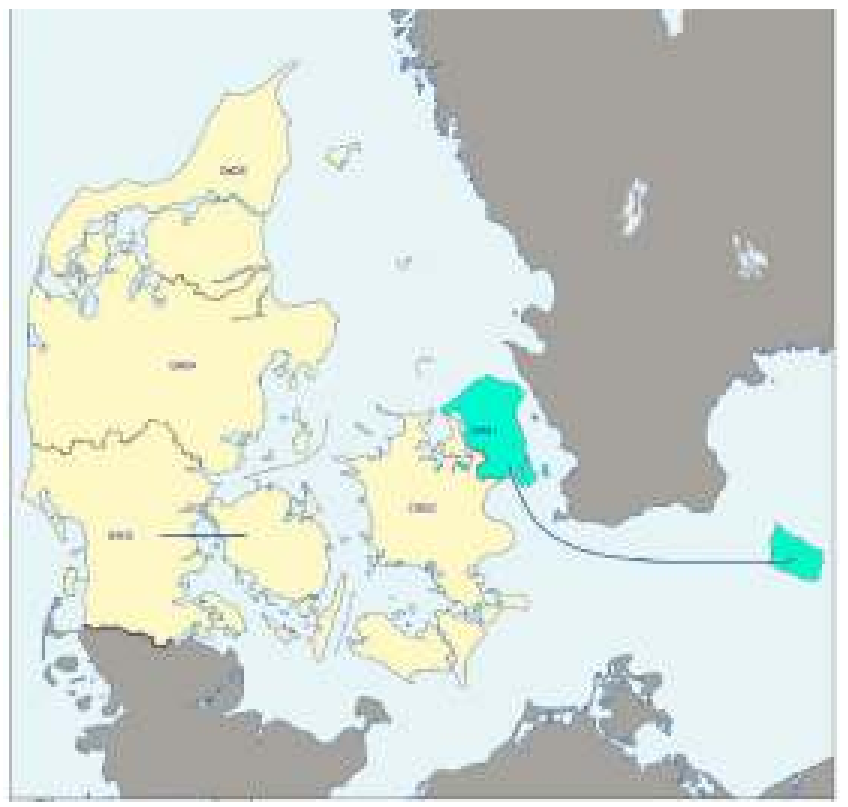

Location of island of Lesvos (Source: Eurostat)

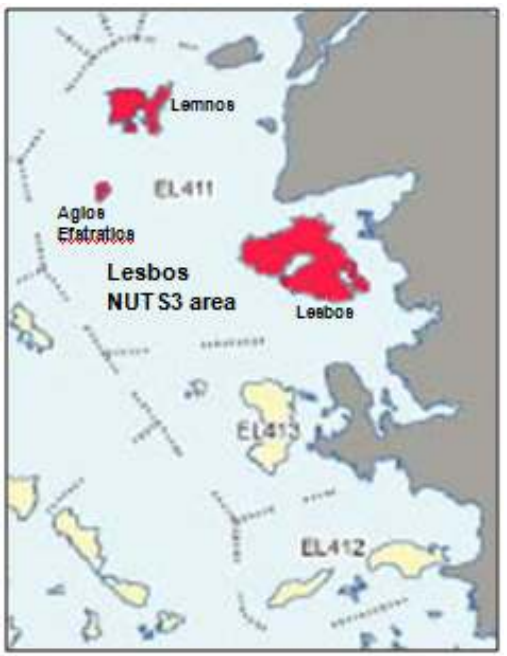

Location of the island of Bornholm

(Source: Eurostat)

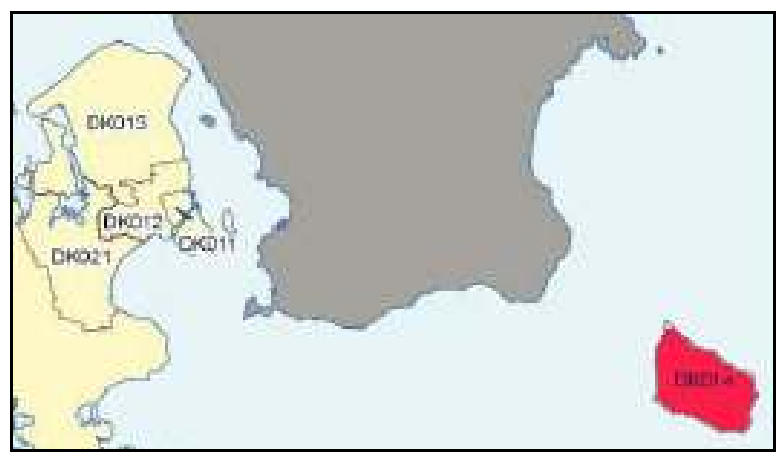


Location of the Highlands and Islands

(Source: Eurostat)

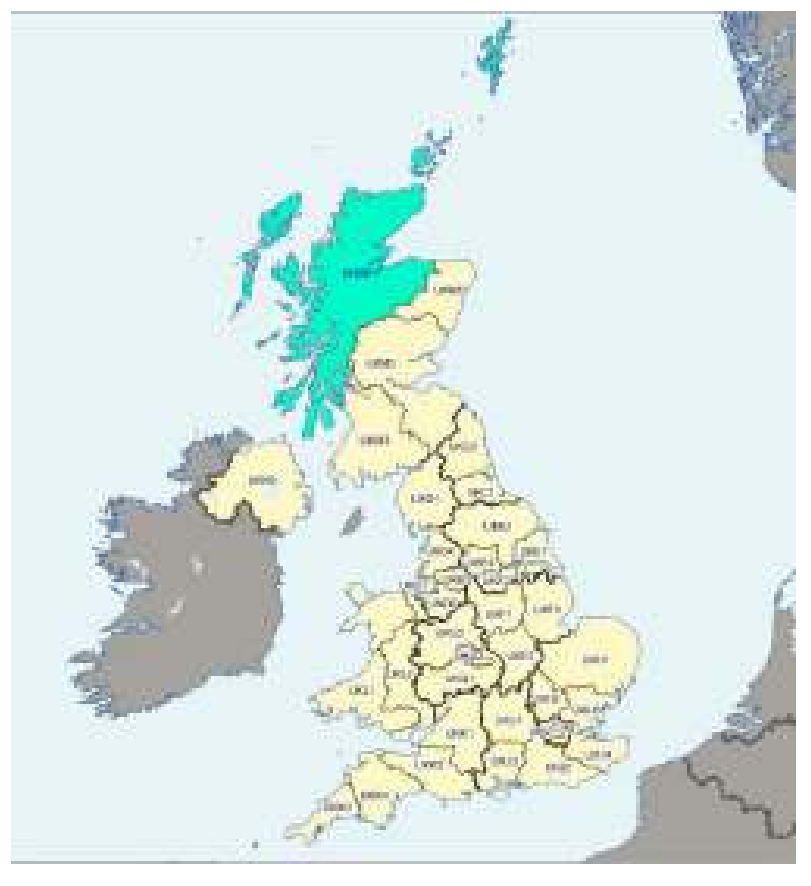

\section{Location of Western Isles of Scotland (Source: Eurostat)}

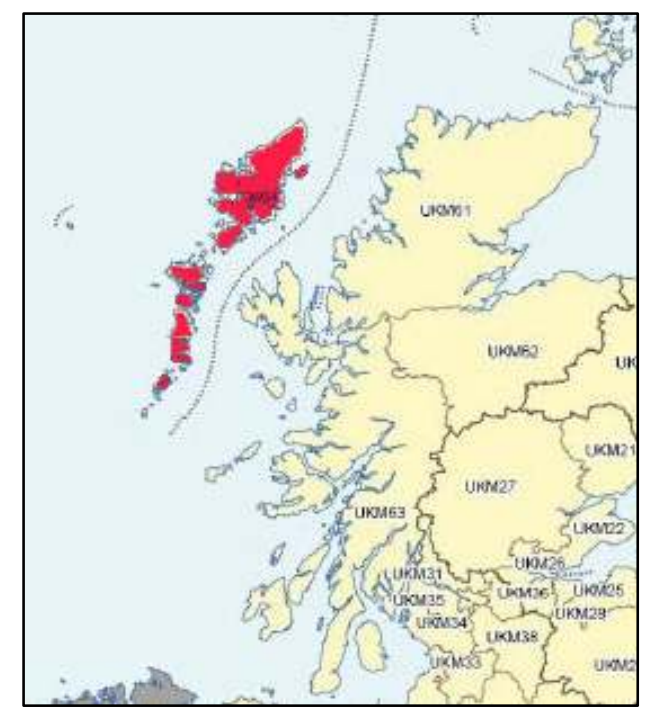

A serious problem facing the research from the start was the absence of a single consensus theory of economic growth for regions. Regional policy interventions such as those of the ERDF typically seek to trigger faster economic growth. They are essentially 'supply-side' policies which rely principally for their success not on the fiscal expenditure stimulus of new spending, but rather on encouraging growth by removing impediments or creating new opportunities. This in turn relies upon there being a good understanding of the underlying determinants of economic growth. However, at the present time, the determinants of economic growth for islands, as with other types of sub-national regions, remain only partially understood and a number of different economic theories have been proposed. These range from traditional neoclassical growth theory through export-led models to newer theories such as endogenous growth theory and new economic geography models (see Armstrong \& Taylor, 2000 for a review). In the absence of a single growth theory, the study adopted the more pragmatic approach of a SWOT (strengths, weaknesses, opportunities and threats) framework. This has two advantages. Firstly, it allowed a holistic approach to be adopted, encompassing as full a set as possible of growth determinants. Secondly, it allowed the study to draw upon ERDF strategy program documents (called Single Programming Documents - SPDs, or alternatively Operational Programs - OPs) which are routinely based on detailed SWOT analyses for each region.

Detailed SWOT checklists were developed for island regions, mountain regions and SPAs (see ADE, 2012, Second Intermediate Report, Annexes 1-3). The SWOT lists formed the basis of the semi-structured interviews, focus groups and other fieldwork. 


\section{Results for Island Case Study Regions}

The results for the three island case study regions have been grouped under three main headings:

\section{Key geographical characteristics.}

An important conclusion of the study was that, from the perspective of the principal policymakers and stakeholders, geographical specificities do indeed matter. This need not necessarily have been the case as most EU islands lie close to the European landmass and rapid improvements in transport and telecommunications have undoubtedly eroded the economic challenge posed by islandness (we follow Baldacchino, 2007a, in using 'islandness' rather than 'insularity' as the latter term has pejorative connotations). The case studies do, however, reveal that the influence of geography is more complex than might be thought, for four reasons:

a) In no case was islandness found to be the sole source of economic challenges. In all three island regions, it was a combination of geographical characteristics which mattered;

b) Remoteness (from EU markets) and the settlement pattern (particularly the widespread characteristic of 'small scattered settlements') were revealed as being of particular importance. Mountainous terrain does not seem to pose such a serious challenge and was frequently seen as a positive attribute;

c) For some of the islands, the problem of 'small scattered communities' was made worse by the geographical configuration of the landscape;

d) Each of the three case study regions exhibited their own unique 'accident of geography' which generated further distinctive challenges.

The case study which best exemplifies all four of these subtle interactions of geographical characteristics was the Western Isles. The Western Isles lie off the north western seaboard of Scotland, making them some of the remotest of all EU islands. In a study of the accessibility of each of NUTS3 regions, Copus (1999) derived a Western Isles accessibility index of 89.53 (on a scale of $0-100$ ), a very high value. More recent accessibility analysis places the Western Isles firmly in the category of 'predominantly rural, remote regions' (Dijkstra \& Poelman, 2008, 2011).

To the challenges of islandness and remoteness in the Western Isles must be added the phenomenon of sparse population. The Western Isles population density in 2007 was only 8.6 persons per $\mathrm{km}^{2}$; the equivalent figure for population density across the wider EU in 2007 was 113 persons per $\mathrm{km}^{2}$. Typically, however, the main challenge of sparse population was not low population density itself, but rather a pattern dominated by small scattered communities. Economic activities struggle to survive in small, widely separated communities and public services are costly to provide. The traditional settlement pattern of the Western Isles was one of tiny rural 'townships'. The challenge posed by the pre-existing pattern of scattered settlements has been exacerbated by recent demographic trends. In a trend typical of many EU islands, increasing 'primacy' in the urban hierarchy has occurred. The islands' capital, Stornoway, has become increasingly dominant and now contains $30 \%$ of the total population of the region. Increasing primacy has occurred against a backdrop of falling total population over 


\section{H. W. Armstrong et al.}

time (a fall of 43\% between 1901 and 2001 and no less than 8.5\% between 1995 and 2005). As a result, individual settlement sizes away from Stornoway have fallen.

The inherent tendency towards small scattered settlements is made worse by an unusual geographical configuration of the landscape, in three ways:

a) The Western Isles are made up of an archipelago of 100 or so islands, resulting in issues of 'islands off islands', or 'double insularity' (Bardolet \& Sheldon, 2008). Depopulation of the smaller islands has led to 13 currently inhabited islands, and the construction since the 1950s of a 'Spinal Route' of bridges and causeways has reduced the archipelago to only three groups of inter-connected islands. Nevertheless, 'double insularity' and the fragmentation of the settlement pattern remains a serious issue;

b) The landscape is one of a complex pattern of sea lochs and peninsulas, further fragmenting the pattern of small scattered settlements;

c) The archipelago's islands straggle in a long north-east to south-west chain stretching 100 $\mathrm{km}$ (giving rise to one of its earliest names: the 'Long Isle'), again making access within the islands difficult.

There is also the Western Isles' own unique 'accident of geography'. The islands are served by two main ferry routes. Unfortunately, the mainland coast facing the islands is itself both sparsely populated and a considerable distance from the H\&I capital of Inverness (on the east coast of Scotland) or other major Scottish cities. Long overland transport must accompany each ferry journey. This situation is ameliorated somewhat by improvements in air transport links over the last twenty years or so in the Scottish islands. The Western Isles have three airports (at Barra in the south, Benbecula in the centre of the chain and at Stornoway in the north, the islands' main airport). There are scheduled inter-island flights as well as direct links to Inverness and Glasgow. While improvements in air transport have undoubtedly greatly reduced the isolation faced by islanders, as is the case for many islands around the world, air transport can only ever partially offset sea transport challenges. Air transport is expensive and is only suitable for certain types of freight and passenger journeys. The Western Isles' inhabitants do, however, benefit from cheaper air fares subsidized by the Scottish government (40\% reductions for registered local inhabitants), but these subsidies do not apply to visitors.

The challenges posed by a combination of geographical characteristics can often be subjective as well as objective. For example, the perception of a challenge such as remoteness can be as important as its (declining) reality: "There is also the issue of the perception of remoteness, both within the region and by outsiders, even though transport access has greatly improved over the years" (Interviewee). This survival of a perception of islandness and remoteness despite major transport improvements has been identified elsewhere in island communities (e.g. Baldacchino, 2007b).

Lesvos is one of nine main islands comprising the Greek NUTS2 region of Voreio Aigaio. Although Voreio Aigaio is not the same kind of free-standing archipelago found in the Western Isles, Lesvos does face major 'double insularity' problems as well as a combination of islandness, remoteness and settlement pattern challenges. The island lies at the extreme eastern periphery of both Greece and the EU. Even the most direct ferry route to Athens is a long one (12 hours on the main route), and Lesvos has a Copus (1999) accessibility index of 95.32, 
more remote even than that of the Western Isles. As with the Western Isles, Lesvos has benefited from improvements in air transport links. Mytilíni has a modern international airport and there are direct charter flights from no fewer than eight northern European countries as well as regular scheduled flights to Athens and Thessaloniki. While superficially Lesvos does not seem to have a sparse population challenge, having a population density of 189.5 persons per $\mathrm{km}^{2}$, it does face an issue of small scattered settlements arising from (a) the configuration of the landscape (it is a mountainous island with a coastline of peninsulas and inlets), and (b) increasing urban primacy around Mytilíni, the administrative capital of the island. The latter has once more occurred against a backdrop of depopulation (a 35\% loss of population between 1951 and 1981, a small recovery of $3.4 \%$ between 1981 and 2001 , but another drop of 4\% between 2001 and 2011). The more rural settlements have been in decline, at least up until the 2008 financial crisis. There is some anecdotal evidence that return migration to smaller remote settlements may have begun to pick up in the aftermath of Greece's savage austerity program, but it is still too early to know how large or how permanent this might prove to be in practice.

Finally, there is Lesvos' own unique 'accident of geography'. The Turkish mainland is extraordinarily close (a mere $5.5 \mathrm{~km}$ at its nearest point). While the Turkish mainland opposite Lesvos is not sparsely populated, it might as well have been. Turkey is not an EU Member State and for historical reasons economic links between Lesvos and Turkey have been strictly limited, even though in recent years some Turkish tourists have been able to visit the island.

Bornholm does not face the same number of different geographical challenges as the Western Isles or Lesvos. It is not part of an archipelago. Nor is it mountainous or sparsely populated, having a population density of 71.2 persons per $\mathrm{km}^{2}$. The island is also a compact one of 589 $\mathrm{km}^{2}$, with good internal transport links from smaller communities to the capital Rønne. The configuration of the landscape is therefore not the issue it is in Lesvos or the Western Isles. On the other hand, it does face a combination of islandness and remoteness (with a high Copus index of 83.29). Moreover, settlement sizes in the rural areas have been affected by depopulation. Bornholm's population peaked in 1965 (at 48,620 persons), but has fallen by $14 \%$ since then.

Finally, there is Bornholm's own unique 'accident of geography'. Bornholm is a free-standing small island lying in the southern part of the Baltic Sea. The island is much closer to Sweden $(37 \mathrm{~km})$, and even Poland $(90 \mathrm{~km})$ and Germany $(88 \mathrm{~km})$ than to the Danish capital city region of Hovestaden of which it is a part $(145 \mathrm{~km})$. As a result, the island's main ferry route is with another member state (i.e. through Ystad in southern Sweden), and as a result of this quirk of geography it is actually quicker to travel from Bornholm to Copenhagen via another Member State than directly! Once again, as with the Western Isles and Lesvos, improvements in air transport have helped to overcome the 'tyranny of distance' imposed by sea transport. Bornholm has regular scheduled flights directly to Copenhagen and there is a program of summer flights to and from Berlin. However, once again it should be noted that air transport is both an expensive option and also only a suitable alternative to the ferry services for certain types of freight and passengers.

\section{Niche market specialization}

Virtually all small island economies are fated to rely on niche markets for their economic prosperity. This is a double-edged sword. Specialization can lead to great prosperity. On the 


\section{H. W. Armstrong et al.}

other hand, it also renders the economies vulnerable to sudden shifts beyond the island's control.

While all the case study regions show clear niche specialization, they also reveal three other features:

a) Existing niche sectors are insufficient to maintain high income levels and full employment. This is, of course, why all three are designated EU regional policy regions, but it is also true that a majority of EU island regions also seem to underperform (Monfort, 2009);

b) Islands do not enjoy the luxury of being able to stand still. In all three regions, it has proved necessary to seek new niches as traditional niches have declined. In the best cases, the islands have sought to build from their strengths and move forward into higher value added niches within the existing sectors. In other cases, this has not proved possible and economic performance has suffered accordingly;

c) Diversifying away from traditional niche sectors into radically new types of business has proved to be extremely difficult. Despite major efforts to do this, progress has been relatively slow in all three regions.

It is interesting to note that these three findings of the study are strongly supported by the wider research literature dealing with remoteness, insularity and vulnerability (e.g. Briguglio et al., 2006; Baldacchino \& Milne, 2000; Eurisles, 2002).

The three case study regions exhibit fascinating differences in how they have sought to develop new niche markets. The Western Isles has a distinctive set of niche sectors. The islands lack oil $\&$ gas and timber resources (unlike other parts of the H\&I region), but do have two very valuable resource-based niches: fishing and fish farming. The former is dominated by high value shellfish (mostly live prawns for shipment to Europe - some 3,200 tonnes in 2009 worth $£ 10.2 \mathrm{~m}$ - US $\$ 15.9 \mathrm{~m}$ at current exchange rates). The latter is dominated by Atlantic salmon fish farming in the islands' sea lochs, generating some 350 local jobs directly and another 200 in processing, marketing and distribution. There are three other main niche sectors:

(a) Tourism, principally activity and 'cold-water' tourism (Baldacchino, 2006), worth $£ 50 \mathrm{~m}$ (US\$78m) in 2007 and generating 1,250 jobs (Snedden Economics, 2007).

(b) Agricultural products, with exports dominated by 'store' sheep and cattle (i.e. animals reared for fattening elsewhere on the mainland), worth $£ 1.2 \mathrm{~m}$ (US\$1.9m) in export earnings in 2003.

(c) Textile, craft and creative industries, based on the islands' distinctive culture. Most notable among these is the world-famous Harris Tweed textile industry (worth $£ 3.9 \mathrm{~m}$, or US\$6.1m, in 2009).

The Western Isles are fortunate in having such a wide array of niche sectors. However, all of the key sectors reveal great vulnerability. Fishing was traditionally dominated by white fish catches. The introduction of strict UK and EU quotas in the 1990s put paid to this valuable niche. The islands then switched to shellfish and fish farming. However, even this has proved volatile. Fish farming expanded rapidly in the 1990s, followed by a large decline in prices leading to a period of employment losses. Tourism has proved to be more stable, but shifts in UK tourism away from traditional summer holidays within the UK has meant that other forms 
of tourism have had to be fostered. Finally, the Harris Tweed industry has also proved vulnerable to external fashion shifts. In the 1990s and early 2000s, demand and production fell sharply before partially reviving after consolidation and major efforts to rebrand the niche as a fashion product (e.g. in handbags).

As with many small islands, declining job opportunities in the main niche export earning sectors have been compensated in part by expanding public sector employment. In 2008 employment in public administration, education and health amounted to $42.6 \%$ of all jobs in the Western Isles, compared to only $32.8 \%$ in the H\&I as a whole (Highlands \& Islands Enterprise, 2009).

While the Western Isles have been able to adapt to changes in their traditional niche sectors, it has proved much harder to develop radically new niches. For example, development of renewable energy for export has proved difficult despite EU support, and the craft and cultural niches (e.g. Gaelic media enterprises) remain very small.

Lesvos and Bornholm give us two very different examples of island adaptation. The Lesvos economy relies most heavily on only two sectors - agriculture (or rather agri-business through food processing) and tourism. Fishing is a small and declining sector. Within the two key export sectors, great sub-sector specialization exists. Agri-food products are dominated by olive oil (with olive trees covering some $40 \%$ of the island), soap production, ouzo spirit production, cheese and specialist products such as gum mastic. Unlike the Western Isles, tourism is mainly of the traditional mass 'sun and sand' category. The agri-food business explains the relatively high proportion of manufacturing in GDP (5.6\% in 2007 compared to $4.8 \%$ in the wider Voreio Aigaio region, though still small compared to the Greece average of $10.4 \%$ ), and also the higher than average contribution of agriculture to GDP (5.8\% in 2007 compared to $3.8 \%$ for Greece as a whole). Tourism has been the most stable of the niche sectors, but not very dynamic. Agri-food products have faced greater challenges. For example, olive oil and soap production sectors began experiencing export competitiveness pressures from the 1950s onwards, and high labour costs in Greece have only been partly offset by inflows of eastern European migrants. In summary, Lesvos has found itself locked into a small set of traditional niche sectors and has struggled to adapt to external changes.

In the case of Bornholm, the economy rests most heavily on summer tourism, food products (particularly dairy products), some limited manufacturing (including metal working and crafts and pottery production) and fishing. The four key export sectors generated directly some 4,600 jobs in 2008 (22.7\% of the total), although many more jobs rely indirectly on export income. Between 1996 and 2008, employment in the traditional agriculture, food processing and fishing sectors fell. Production levels in agriculture, manufacturing and tourism niches have fortunately held up. The best example of niche volatility has been fishing. This was a major employment and export sector until the 1980s, when the introduction of quotas in response to declining fish stocks greatly affected the industry. As shall be shown later, of all three island case studies, Bornholm has proved to be the most radical in seeking to develop new niches, particularly in 'green tourism', new industrial clusters and renewable energy. This has not, however, been easy.

\section{The demographic challenge}

The most striking feature revealed by the study for all three island case studies is the scale of the demographic challenge of depopulation. The settlement pattern implications of falling 


\section{H. W. Armstrong et al.}

population have already been discussed. There are, however, other more important impacts. Depopulation undermines island industries and puts public service provision under severe pressure. More serious still is the loss of younger, more economically active people. In Bornholm, population decline since 1965 has been greatest among 20-29 year olds. This in turn has triggered a fall in birth rates too, leading forecasters to predict a further population fall to 39,470 inhabitants by 2021 . This vicious circle, with an ageing population that is becoming ever more elderly, is occurring in all three case study regions.

Lesvos has had almost continuous population decline since 1951. A temporary population recovery of 3.4\% over 1981-2001 was the result of return migration and in-migration flows from Eastern Europe rather than natural increase. Deaths have exceeded births on Lesvos for the last 50 years. By 2001, Lesvos had an 'ageing index' (i.e. people over 65 divided by people under 15 years of age) of 145, compared to a Greek national average of 110.

The Western Isles have faced even bigger problems. Population has fallen continuously since 1901, falling 43\% between 1901 and 2001. The period 2001-2009 saw a further fall of $1 \%$. Between 2001 and 2008, the percentage aged 65 and over rose from $20 \%$ to $21 \%$, while those under 44 fell from 53\% to 50\%: "the demographics for the Western Isles still look horrendous

... The issues are just as stark as ever" (Interviewee). Some in-migration for 'lifestyle' reasons has occurred in the Western Isles (as in the other two regions), but is nowhere near enough to offset the loss of young people (Hall Aitken, 2007).

4. The ERDF programs in 2000-06 and 2007-13.

ERDF policy initiatives were classified in the study into three broad groups:

(a) Reactive policies - those defensive in nature and designed to mitigate or offset particular geographical weaknesses or threats (e.g. transport links);

(b) Proactive policies - designed to exploit island strengths and opportunities (e.g. craft enterprises exploiting island culture);

(c) Sustainability policies - those seeking to exploit islands as 'laboratories' for developing more environmentally sustainable economic development. None of the three case studies have sought to go as far as Samsø in Denmark which has a fully carbon neutral strategy (Samsø Energy Academy, 2007); but all three case studies have major sustainability components.

This classification has the advantage of pin-pointing the extent to which an island has managed to move on from traditional views of islandness as a set of problems to more forward looking policies seeking to build on island strengths.

The 2000-06 and 2007-13 programs differ greatly in scale between the three regions. Lesvos is part of the Voreio Aigaio NUTS2 region and was eligible in both 2000-06 and 2007-13 for help as part of an Objective 1 ('Convergence') region. Objective 1 regions are much more generously funded than Objective 2 ('Regional Competitiveness and Employment') regions. Uniquely amongst the three case studies, it was also eligible for Cohesion Fund (CF) assistance, Greece having a GDP per capita under 90\% of the EU average. The Western Isles are part of the H\&I region of Scotland and in both 2000-06 and 2007-13 were eligible for 
'transition' funding (having been an Objective 1 region in 1994-99). Bornholm was part of Denmark's sole Objective 2 program in both periods, and hence had the least generous ERDF funding of all three case studies.

Lesvos, and the wider Voreio Aigaio region of which it is part, was not just better funded in both 2000-06 and 2007-13, but also experienced an increasing EU budget. ERDF/CF allocations for Voreio Aigaio rose from $€ 358.5 \mathrm{~m}$ to $€ 373 \mathrm{~m}$ between $2000-06$ and 2007-13. In Denmark, overall EU allocations for the Objective 2 program were $€ 137 \mathrm{~m}$ in $2000-06$, of which Bornholm received $€ 8.5 \mathrm{~m}$. For the 2007-13 period, Denmark's allocation for the Regional Competitiveness and Employment objective rose to $€ 254 \mathrm{~m}$, although Bornholm's share of this fell to $€ 7.5 \mathrm{~m}$. By contrast, ERDF allocations for the H\&I region fell from $€ 190 \mathrm{~m}$ in 2000-06 to $€ 122 \mathrm{~m}$ in 2007-13.

An important feature of ERDF programs in the three regions concerns their governance arrangements. In all three cases, the islands had to function within programs designed for a wider eligible region. This caused major difficulties in tailoring the wider economic development strategy to the particular needs of the islands, and especially so for Lesvos. This island was part of the Voreio Aigaio administrative region in both periods, but the 2000-06 Objective 1 program actually covered the whole of Greece. While separate broad regional programs were developed within the national Objective 1 program, they were at a level well above that of Lesvos, and the Greek Objective 1 program also had a series of sectoral programs running at national level (e.g. transport). The 2007-13 Operational Program, of which Lesvos is part, covers several different Greek NUTS2 regions, broader even than Voreio Aigaio, and again there are some national level sector initiatives.

The Western Isles has had rather more policy latitude than Lesvos, but shared the same conundrum of being part of a wider (H\&I) geographical program. Moreover, H\&I programs were designed with mainland areas in mind as well as islands. Bornholm has had the most freedom of all the case study regions to develop a more tailored program. This is because it has been granted the unusual status within the Danish system of a combined regional and local government, and in 2007 was granted its own 'Regional Forum' of partners to design economic development strategy. It was also given considerable freedom within the ERDF programs themselves to allocate the funding. Nevertheless, even in the Bornholm case, the Objective 2 program is essentially a national one, of which Bornholm is only a small part.

Since in all three cases the islands are part of wider ERDF program areas, a key consideration is how the islands' shares of the ERDF budget are determined. In the case of the Western Isles a deliberate decision was taken not to divide up the 'cake' into pre-determined shares, but rather to allow each sub-region's share to be determined by the quality of projects eventually put up for approval. During 2000-06, the Western Isles obtained some $€ 13 \mathrm{~m}$ (or 7\% US\$16.1m) of the full H\&I spending, equivalent to the value of $€ 494$ per capita (US\$612), well in excess of the H\&I average of $€ 429$ (US\$532). Equivalent figures for 2007-13 are not yet available as the program is on-going. In the case of Lesvos and Bornholm, more formal procedures were adopted to guarantee their budget shares. Different islands within Voreio Aigaio are allocated shares based on population size, giving Lesvos a 52\% share in both 200006 and 2007-13. Bornholm was pre-allocated a share of 6.6\% in 2000-06. This fell, however, to only $2.9 \%$ in $2007-13$. 
Turning to the nature of the ERDF interventions, commitments can be analyzed by broad 'fields of intervention'. These are shown in Table 1 below.

Table 1: Allocations by Field of Intervention, 2000-06.

\begin{tabular}{|c|c|c|c|c|c|c|c|}
\hline Field of intervention & $\begin{array}{c}E U \\
\text { Obj. } 1\end{array}$ & $\begin{array}{l}\text { Voreio } \\
\text { Aigaio }\end{array}$ & Lesvos & $\begin{array}{c}E U \\
\text { Obj. } 2\end{array}$ & $\begin{array}{l}\text { Denmark } \\
\text { Obj. } 2\end{array}$ & Bornholm & $\begin{array}{c}H \& I \\
\text { Region }\end{array}$ \\
\hline Agriculture & 0.1 & 0.0 & 0.0 & 0.2 & 0.0 & 0.0 & 0.0 \\
\hline Forestry & 0.0 & 0.0 & 0.0 & 0.1 & 0.0 & 0.0 & 0.0 \\
\hline $\begin{array}{l}\text { Adaptation and } \\
\text { development of rural areas }\end{array}$ & 0.4 & 0.0 & 0.0 & 2.5 & 4.1 & 0.3 & 0.0 \\
\hline Fisheries & 0.1 & 1.6 & 0.3 & 0.0 & 0.0 & 0.0 & 0.0 \\
\hline Assisting large businesses & 5.8 & 0.7 & 0.6 & 5.1 & 2.3 & 1.6 & 0.0 \\
\hline $\begin{array}{l}\text { Assisting SMEs and craft } \\
\text { firms }\end{array}$ & 9.6 & 5.1 & 5.2 & 31.2 & 28.6 & 33.8 & 35.6 \\
\hline Tourism & 2.9 & 5.4 & 4.0 & 10.2 & 30.4 & 1.6 & 4.8 \\
\hline $\begin{array}{l}\text { Research, technological } \\
\text { development and } \\
\text { innovation (RTDI) }\end{array}$ & 6.2 & 2.0 & 1.9 & 10.1 & 14.6 & 6.9 & 3.6 \\
\hline Labour market policy & 0.1 & 0.0 & 0.0 & 0.1 & 0.0 & 0.0 & 0.0 \\
\hline Social inclusion & 0.1 & 0.0 & 0.0 & 0.7 & 0.0 & 0.0 & 0.0 \\
\hline $\begin{array}{l}\text { Education and vocational } \\
\text { training }\end{array}$ & 1.5 & 0.7 & 0.7 & 1.4 & 0.0 & 0.0 & 0.0 \\
\hline $\begin{array}{l}\text { Workforce flexibility, } \\
\text { entrepreneurial activity, } \\
\text { innovation and ICT }\end{array}$ & 0.0 & 0.0 & 0.0 & 0.4 & 0.0 & 0.0 & 0.0 \\
\hline $\begin{array}{l}\text { Positive labour market } \\
\text { actions for women }\end{array}$ & 0.0 & 0.0 & 0.0 & 0.1 & 0.0 & 0.0 & 0.0 \\
\hline Transport infrastructure & 34.0 & 26.8 & 24.1 & 7.7 & 7.4 & 14.2 & 31.9 \\
\hline $\begin{array}{l}\text { Telecommunications } \\
\text { infrastructure }\end{array}$ & 3.2 & 16.2 & 14.8 & 2.9 & 5.2 & 33.3 & 6.7 \\
\hline Energy infrastructure & 1.0 & 0.0 & 0.0 & 0.8 & 0.2 & 0.5 & 4.0 \\
\hline $\begin{array}{l}\text { Environmental } \\
\text { infrastructure }\end{array}$ & 19.3 & 27.1 & 38.8 & 5.2 & 0.0 & 0.0 & 3.2 \\
\hline Planning and rehabilitation & 10.1 & 8.6 & 6.2 & 17.0 & 5.0 & 4.2 & 0.0 \\
\hline $\begin{array}{l}\text { Social and public health } \\
\text { infrastructure }\end{array}$ & 4.2 & 4.9 & 3.0 & 1.9 & 0.0 & 0.0 & 7.6 \\
\hline Technical assistance & 1.4 & 0.9 & 0.4 & 2.3 & 2.0 & 3.5 & 2.5 \\
\hline Total & 100.0 & 100.0 & 100.0 & 100.0 & 100.0 & 100.0 & 100.0 \\
\hline Productive environment & 25.1 & 14.7 & 12.0 & 59.5 & 80.0 & 44.3 & 44.1 \\
\hline Human resources & 1.8 & 0.7 & 0.7 & 2.7 & 0.0 & 0.0 & 0.0 \\
\hline Basic infrastructure & 71.7 & 83.6 & 86.9 & 35.6 & 17.9 & 52.2 & 53.4 \\
\hline Technical assistance & 1.4 & 0.9 & 0.4 & 2.3 & 2.0 & 3.5 & 2.5 \\
\hline
\end{tabular}

Notes: 1. 'Human resources' (i.e. labour market policy and other initiatives in the central part of the table) is essentially an ESF responsibility and is thus not considered further here. 2. Separate data do not exist for the Western Isles.

3. Figures are percentages of the total ERDF/CF budget.

Source: European Commission SWECO database. 
Three key features emerge from Table 1:

ERDF policies in Lesvos in 2000-06 were very different from those in Bornholm and in the Scottish H\&I region. In particular, Lesvos saw much more of the budget targeted on basic infrastructure projects $(86.9 \%)$ than either Bornholm $(52.2 \%)$ or the H\&I region $(53.4 \%)$. This is partly a reflection of the fact that Lesvos is an Objective 1 region. Objective 1 regions have larger grant rates for infrastructure projects and EU regional policy encourages greater infrastructure spending there. However, Lesvos has clearly taken a deliberate decision to adopt a stronger infrastructure element than other EU Objective 1 regions $(71.7 \%)$, and has an even higher infrastructure commitment than the Voreio Aigaio region of which it is part. As can be seen, in Lesvos three main types of infrastructure projects have prevailed: environmental infrastructure such as water supply (38.8\%), transport infrastructure $(24.1 \%)$ and telecommunications infrastructure $(14.8 \%)$.

In contrast, Bornholm and the H\&I region committed much more of the budget in 2000-06 to 'softer' productive environment initiatives (e.g. business advice, grants and loans to firms etc). These made up $44.3 \%$ of the budget in Bornholm and $44.1 \%$ in the H\&I region. The switch from infrastructure to business support is what one would expect for all Objective 2 regions ('Growth and Competitiveness' regions). The particular focus in Bornholm and H\&I on SMEs and craft firms (33.8\% and $35.6 \%$ of the budget respectively) is noteworthy, being greater than the overall Objective 2 average $(31.2 \%)$.

However, the two Objective 2 island regions do still have a lot of basic infrastructure spending. Bornholm put $52.2 \%$ of its $2000-06$ budget into basic infrastructure while the equivalent figure for the H\&I was 53.4\%. The overall EU Objective 2 figure was only 35.6\%. Table 1 shows that there was a big difference between Bornholm and the H\&I region in the type of infrastructure assisted. Bornholm was much more focused on telecommunications (a massive $33.3 \%$ ) while the H\&I region favoured transport infrastructure projects.

In summary, in 2000-06 the island regions tended to put a lot more emphasis on infrastructure projects than their wider EU counterparts, and amongst the three case studies Lesvos was extremely heavily committed to infrastructure policies, while Bornholm and the H\&I region had by 2000-06 moved on to somewhat more of the softer business support policies.

Turning to the 2007-13 program period, the new regional strategies were developed against a backdrop of the European Commission requiring regional policy to focus much more closely on the so-called Lisbon Agenda objectives of better business competitiveness, growth and environmental sustainability, implying more help for softer business support measures and less for basic infrastructure. In practice, this change was much more prominent among Objective 2 regions than Objective 1 areas such as Lesvos.

In order to ascertain whether the Western Isles have followed the desire to embrace the Lisbon Agenda, an analysis was undertaken of the actual projects approved by the time of the study (August 2011). Projects were classified as reactive, pro-active or sustainability ones. The exercise was conducted separately for the 17 Western Isles ERDF projects approved by August 2011 under the 2007-13 program as well as for the full set of projects approved for the complete H\&I region of which the Western Isles are a part. Table 2 presents the results. This exercise was done only for the Western Isles and not for Bornholm or Lesvos. 
Table 2: A Classification of ERDF Approved Projects in the Western Isles and H\&I Region, August 2011. Figures in the table are percentages of the total number of projects in each category.

\begin{tabular}{|c|c|c|}
\hline Type of project & $\begin{array}{l}\text { Western Isles } \\
\text { NUTS3 Region }\end{array}$ & $\begin{array}{l}\text { Highlands \& Islands } \\
\text { NUTS2 Region }\end{array}$ \\
\hline Accessibility - communications within sub-region & 41.2 & 22.7 \\
\hline $\begin{array}{l}\text { Accessibility - communications across the wider } \\
\text { H\&I region }\end{array}$ & 0.0 & 4.5 \\
\hline Sparse population - general & 0.0 & 0.0 \\
\hline Sparse population - specific scattered communities & 47.1 & 21.6 \\
\hline Islandness (including 'double insularity') & 17.6 & 10.2 \\
\hline Mountain terrain & 0.0 & 0.0 \\
\hline $\begin{aligned} & \text { Reactive } \\
&- \text { Infrastructure } \\
&- \text { Other } \\
&\end{aligned}$ & $\begin{array}{l}5.9 \\
0.0\end{array}$ & $\begin{array}{c}10.2 \\
0.2 \\
\end{array}$ \\
\hline $\begin{aligned} \text { Reactive, builds on earlier project ('gap filling') } \\
-\quad \text { Infrastructure } \\
-\quad \text { Other } \\
\end{aligned}$ & $\begin{array}{c}35.3 \\
0.0\end{array}$ & $\begin{array}{l}9.1 \\
0.0\end{array}$ \\
\hline $\begin{array}{l}\text { Proactive - makes geographical characteristic a } \\
\text { positive virtue } \\
\text { - } \text { Infrastructure } \\
\text { - } \text { Other }\end{array}$ & $\begin{array}{l}0.0 \\
0.0\end{array}$ & $\begin{array}{l}0.0 \\
0.0\end{array}$ \\
\hline $\begin{array}{l}\text { Proactive - exploits a natural or cultural asset } \\
-\quad \text { Infrastructure } \\
-\quad \text { Other } \\
\end{array}$ & $\begin{array}{l}23.5 \\
17.6 \\
\end{array}$ & $\begin{array}{l}28.4 \\
29.5\end{array}$ \\
\hline $\begin{array}{l}\text { Environmental sustainability (e.g. renewable } \\
\text { energy) } \\
\quad-\quad \text { Infrastructure } \\
\quad-\quad \text { Other }\end{array}$ & $\begin{array}{c}11.8 \\
0.0\end{array}$ & $\begin{array}{c}14.8 \\
9.1\end{array}$ \\
\hline $\begin{aligned} & \text { Sectoral focus - general } \\
&- \text { Traditional sectors } \\
&- \text { Newer sectors } \\
&\end{aligned}$ & $\begin{array}{l}35.3 \\
76.5\end{array}$ & $\begin{array}{l}20.5 \\
69.3 \\
\end{array}$ \\
\hline $\begin{aligned} & \text { Sectoral focus - key driver sectors } \\
&- \text { Renewable energy (community use) } \\
& \text { - } \text { Renewable energy (export) } \\
&- \text { New forms of tourism } \\
&- \text { Aquaculture } \\
&- \text { Creative and media industries } \\
&- \text { Textiles and other manufacturing } \\
&- \text { E-businesses } \\
&- \text { Life \& health sciences } \\
&- \text { Food \& drink }\end{aligned}$ & $\begin{array}{c}5.9 \\
0.0 \\
35.3 \\
5.9 \\
5.9 \\
0.0 \\
0.0 \\
0.0 \\
0.0\end{array}$ & $\begin{array}{c}21.6 \\
6.8 \\
43.2 \\
0.0 \\
8.0 \\
2.2 \\
4.5 \\
0.0 \\
2.3\end{array}$ \\
\hline
\end{tabular}

Note: Figures do not add to $100 \%$ since the classification is not mutually exclusive. Source: Own research. 
Caution must be exercised in interpreting the results, for two reasons. Firstly, the 2007-13 program still has some distance to run and the figures in the table refer only to projects approved by August 2011. However, this is much less of a problem than might appear at first sight since by August 2011 the vast bulk of the EU funds had been committed. Secondly, Table $\underline{2}$ does not include figures for ERDF money spent by Highlands \& Islands Enterprise (HIE), the government-funded regional development agency. HIE was block allocated funding at the start of the program for use within their already established business support programs for firms. Separate figures for Western Isles involvement in HIE projects were collected (see below). These refer for the period up to 15 June 2011.

Table 2 shows how ERDF money is actually being put to use within the Western Isles during 2007-13, as distinct from SPD aspirations.

(a) The two largest categories of Western Isles ERDF project funding are schemes to help scattered communities (47.1\%) and within-islands accessibility improvement schemes (41.2\%). The latter are almost all 'gap filling' transport schemes, which in the Western Isles usually comprise improving link roads to the so-called Central Spine of causeways and bridges running the length of the archipelago;

(b) In terms of types of projects, in the Western Isles approximately half are reactive, but mostly in the sense of building on projects started in earlier programs rather than new reactive initiatives in their own right. Again, most of these are 'gap filling' transport schemes. The other half are pro-active, mostly seeking to exploit newer forms of tourism and to a lesser extent media and culture (including the important Gaelic culture of the Western Isles);

(c) Renewable energy projects are thin on the ground in the Western Isles and are dominated by local community schemes rather than producing electricity for export. The Western Isles is unfortunate in lacking sufficient undersea cable capacity to exploit its massive renewable energy (offshore and onshore) potential. It will require major infrastructure investment both within the islands and in the form of an undersea cable to the mainland and a cross-Scotland cable to the east coast electricity grid for this potential to be unlocked;

(d) Comparing the Western Isles with the wider H\&I region, it can be seen that the islands remain more dependent on reactive communications projects and on community level initiatives than the rest of the region. On the other hand, the islands have embraced the need to develop newer sectors and types of businesses on a greater scale than the rest of the region ( $76.5 \%$ to $69.3 \%$ ). Most of these are in newer forms of tourism (especially activity and cold-water tourism) as the bottom row of Table 2 shows;

(e) Most striking of all is the apparent difficulty being faced in the Western Isles in joining what the rest of the H\&I region is developing: what are seen as 'key driver' industries (i.e., industrial clusters for the future). We have already seen the problems faced in developing renewable energy for export in the Western Isles. However, other H\&I 'key driver' sectors such as Health \& Life Sciences and Food \& Drink (the latter a particular Scottish success story) are largely missing from the Western Isles. Only in Aquaculture (especially fish farming) do the islands seem to have a comparative advantage. The islands clearly, 


\section{H. W. Armstrong et al.}

therefore, are being forced to specialize on a narrower set of niche sectors for the future than other parts of the H\&I region. This weakness is also revealed when the ERDF funded HIE schemes omitted from Table 2 are considered. By June 2011, the Western Isles had received business support help under eight separate HIE programs amounting to only $7.6 \%$ of all firms assisted in H\&I. In contrast, the Inner Moray Firth sub-region around the H\&I capital of Inverness, and where many of the regions new growth sectors are based, obtained $32.7 \%$ of HEI help. This was not deliberate HIE policy. It simply reflects demand for the schemes.

While the Western Isles continues to struggle to move on from a reactive policy focus, Bornholm had already by 2000-06 taken more radical steps in developing new niches. For its 2007-13 program, Bornholm was faced with a small reduction in its EU budget (down from $€ 8.5 \mathrm{~m}$ in $2000-06$ to $€ 7.5 \mathrm{~m}$, or US $\$ 11.7 \mathrm{~m}$, in $2007-13$, at current 2012 exchange rates here and elsewhere where dollar values are given). There are four priorities in the 2007-13 program: innovation (30\% of the budget), utilization of new technology $(20 \%)$, entrepreneurship $(20 \%)$ and technical assistance (20\%). Bornholm has chosen to align its ERDF spending closely with a new economic development strategy established by the Bornholm Growth Forum set up in 2007. Bornholm's Growth Forum was the first to introduce an industrial cluster emphasis into regional policy in Denmark. Attempts are being made to develop key clusters based around the island's pre-existing strengths (agriculture, food products, light industry \& engineering and construction). However, the strategy is more radical than merely protecting established strengths. New niches are being actively sought, with softer types of business support leading the way. The focus is on harnessing new technology to widen and refresh the business base, to re-brand tourism as an 'experience island', and to systematically use policy help to establish Bornholm as a 'green test island' or 'Bright Green Island'. The 'green test island' policy is designed to develop Bornholm as "the setting for a wide range of Danish and international experiments and demonstration projects focusing on electric cars, solar panels, energy-efficient construction and the development of an intelligent electricity system" (Bornholms Regionscommune, 2012). This is one component of a wider strategy introduced in 2008, and designed to be completed in 2014, to fully re-brand all aspects of the island's economy as the 'Bright Green Island'. Eventually, it is hoped that the island will become wholly energy selfsufficient (ibid.). How successful these new policies will be remains to be seen. The strategy does, however, mark a radical step forward from the reactive policies of the past towards proactive and sustainability schemes.

In stark contrast, Lesvos does not seem to have attempted a significant shift in strategic priorities in 2007-13 compared to 2000-06. The need to try to widen the economic base of the islands continued to be stressed in the 2007-13 OP, but in practice the different types of infrastructure investment continue to predominate, as Table 3 shows. The lack of focus on new economic activities and more modern niche market activities is surprising, especially as the key niche sectors (as we have seen in agriculture, food products and tourism) have lost export competitiveness in recent years and even tourism has stagnated. The need to develop new niches is therefore pressing. This does not seem to be well reflected in the program strategy. 
Table 3: Allocations by field of intervention, 2000-06 and 2007-13, Voreio Aigaio region.

\begin{tabular}{|l|c|c|c|c|}
\hline \multicolumn{2}{c}{$2000-06$ Program } & \multicolumn{2}{c|}{$2007-13$ Program } \\
\hline Field of intervention & $\epsilon m$ & $\%$ & $\epsilon m$ & $\%$ \\
\hline Eransport & 121.8 & 34.3 & 120.6 & 32.3 \\
\hline Communications & 53.9 & 15.2 & 39.2 & 10.5 \\
\hline Protection of the environment & 1.6 & 0.5 & 1.9 & 0.5 \\
\hline Natural heritage & 54.5 & 13.5 & 54.9 & 14.7 \\
\hline Cultural industries & 2.7 & 0.7 & 11.0 & 2.9 \\
\hline Urban regeneration & 40.0 & 11.2 & 15.5 & 4.2 \\
\hline Access of women to work & 6.6 & 1.9 & 28.4 & 7.6 \\
\hline Educational infrastructure & 20.3 & 5.7 & 14.4 & 3.9 \\
\hline Health and social care infrastructure & 35.5 & 10.0 & 42.6 & 11.4 \\
\hline Total & 21.6 & 6.1 & 44.5 & 11.9 \\
\hline
\end{tabular}

Note: Major changes in Priority names and component elements make it difficult to compare like with like. Reclassification by authors has proved necessary.

Sources: 2000-06 and 2007-13 Operational Programs and own calculations.

Table 3 shows that transport infrastructure spending remains high $(32.3 \%$ in $2007-13$, almost the same as in 2000-06), and heavy spending is continuing in all of the other main infrastructure categories. There has been a small increase in natural heritage projects, but note the drop in the share of help for the cultural industries. The overall picture is therefore one of continued reliance on reactive policies and within this category on hard infrastructure projects.

\section{Conclusion}

The study has produced five main findings. Firstly, it is dangerous to consider islandness in isolation from other geographical challenges to economic development. This is not a new finding, but it is interesting that the case study islands have confirmed that islandness cannot be taken in isolation from other challenges. The interactions of the different geographical challenges can also be very subtle. For example, mountainous terrain was not revealed to be as serious a challenge as the other two EU 'specific geographical features'. Moreover, while sparse population was seen as a serious challenge, it appears to affect regions principally because it is associated with a pattern of scattered small settlements rather than through low population density per se. Islandness is also affected by other geographical features such as the configuration of the landscape and unique 'accidents of geography'. Perhaps the most serious concern facing the case study islands is the demographic challenge of depopulation and an ageing workforce. Given falling birth rates right across the wider EU, it is likely that many other EU islands also face similar demographic challenges to those of the case study islands.

Secondly, the islands were shown to be heavily dependent on niche market specialization. Some of these were very successful and suggest how islands could succeed in moving into higher value added niches (e.g. Harris Tweed). However, in all three case studies: (a) the existing niches are insufficient to sustain full employment and prosperity, and (b) all have struggled to develop wholly new niches; most have had to rely on consolidating their existing niches. 


\section{H. W. Armstrong et al.}

Thirdly, while ERDF programs proved to be valuable and generated many benefits, the islands continue to be over-focused on reactive policies. These are 'defensive' policies designed to mitigate the geographical challenges (e.g. transport and telecommunications infrastructure to overcome the 'tyranny of distance'). Pro-active policies are growing in number and there is a welcome subtle shift in views from islandness being seen as a problem to being an opportunity. Nevertheless, there is still not enough of this type of policy or of success yet in developing sustainable growth. In this respect, there are huge differences among the three case studies, with Bornholm being much further along this road than Lesvos. The Western Isles are somewhere in between.

Fourthly, the study revealed just how many similarities in strengths, weaknesses, opportunities and threats the islands, mountain regions and SPAs shared. The number of similarities greatly exceeded the differences (e.g. importance of demography and settlement patterns). This is not to argue that the separate analysis of each type of region is unnecessary. On the contrary, there is enormous variation in both the subtleties of the combinations of geographical challenges faced, and the policy strategies appropriate to them. This variation is great within each geographical category. Care must therefore be taken in deriving generalizations and each case should be seen on its own merits.

Finally, the study has shown that, where islands are part of a bigger administrative unit (as is the case with all three islands in this study), additional constraints and limitations can sometimes arise in the manner in which ERDF policies are designed and implemented. The three case study islands each in their own way sought to adapt to the need to work closely in partnership with the larger administrative authority of which they were part. There is wide variation across the EU in how much administrative autonomy particular islands have, but the majority of EU islands do find themselves being part of bigger administrative units and lack the kind of wider autonomy that island states and sub-national island jurisdictions enjoy.

\section{Acknowledgements}

The research for this paper was financed by the European Commission in the context of the "Study on the relevance and the effectiveness of ERDF and Cohesion Fund support to Regions with Specific Geographical Features - Islands, Mountainous and Sparsely Populated areas" (Contract: 2010.CE.16.0.AT.059). The views expressed here are those of the authors and do not represent the official views of the European Commission. Moreover, any remaining errors or misunderstandings are the responsibility of the authors. In addition to the European Commission, we thank all the respondents that participated in the research interviews on the three islands of Lesvos, Bornholm and the Western Isles. We also thank two anonymous referees for their most useful comments and suggestions on an earlier draft.

\section{References}

ADE - Aide à la Décision Économique (2012) Study on Relevance and Effectiveness of ERDF and Cohesion Fund Support to Regions with Specific Geographical Features: Islands, Mountainous and Sparsely Populated Areas, Final Report, Brussels, European Commission, $\mathrm{http} / /$ ec.europa.eu/regional_policy/sources/docgener/evaluation/pdf/eval2007/geographical_final1.pdf; http://ec.europa.eu/regional_policy/sources/docgener/evaluation/pdf/eval2007/geographical_final2.pdf 
Armstrong, H.W. \& Taylor, J. (2000) Regional Economics and Policy, Oxford, Blackwell.

Baldacchino, G. (2006) 'Warm Versus Cold Water Tourism: A Review of Policy Implications', Island Studies Journal, Vol. 1, No. 2, pp. 183-200.

Baldacchino, G. (2007a) 'Introducing a World of Islands', in G. Baldacchino (ed.) A World of Islands, Malta \& Canada, Agenda Academic \& University of Prince Edward Island, pp. 1-29.

Baldacchino, G. (2007b) Bridging Islands: The Impacts of Fixed Links, Charlottetown, Canada, Acorn Press.

Baldacchino, G. \& Milne, D. (eds.) (2000) Lessons from the Political Economy of Small Islands: The Resourcefulness of Jurisdiction, Basingstoke, Macmillan.

Bardolet, E. \& Sheldon, P.J. (2008) 'Tourism in Archipelagos: Hawaii and the Balearics', Annals of Tourism Research, Vol. 35, No. 4, pp. 900-923.

Bornholms Regionscommune (2012) www.bornholm.dk

Briguglio, L., Cordina, G. \& Kisanga, E. (2006) Building the Economic Resilience of Small States, Malta and London, Islands \& Small States Institute, University of Malta and Commonwealth Secretariat.

Constantino, T.E. \& Greene, J.C. (2003) 'Reflections on the Use of Narrative in Evaluation', American Journal of Evaluation, Vol. 21, No. 1, pp. 35-49.

Copus, A.K. (1999), A New Peripherality Index for the NUTSIII Regions of the European Union, ERDF Study 98/00/27/130, Brussels, University of Aberdeen/European Commission.

Djikstra, L. \& Poelman, H. (2008) Remote Rural Regions: How Proximity to a City Influences the Performance of a Region, Brussels, European Commission, Working Paper 01/2008, DG Regional Policy.

Djikstra, L. \& Poelman, H. (2011) Regional Typologies: A Compilation, Brussels, European Commission DG Regional Policy Working Paper 01/2011.

ESPON - European Spatial Planning Observatory Network (2011) Euroislands Project: Draft Final Report, www.espon.eu and http://geoellanikos.aegean.gr/espon/index.php

Eurisles (2002) Off the Coast of Europe: European Construction \& the Problem of the Islands, Ajaccio, Corsica, for Islands Commission, Conference of Peripheral \& Maritime Regions.

European Commission (1996) The Structural Funds and Cohesion Fund 1994-99: Regulations and Commentary, Luxembourg, Office for Official Publications of the European Communities.

European Commission (2006) Regions \& Cities for Growth and Jobs: Overview of Regulations 2007-13 in Cohesion \& Regional Policy, Brussels, Inforegio Factsheet, DG Regional Policy.

European Commission (2012a) The Outermost Regions: Regions of Assets and Opportunities, Brussels, Regional Factsheet, DG Regional Policy.

European Commission (2012b) EVALSED: Evaluation and Socio-Economic Development, European Commission, DG Regional Policy, Brussels, http://ec.europa.eu/regional_policy/information/evaluations 
Eurostat (1994) Portrait of the Islands, Luxembourg, Office for Official Publications of the European Communities.

Flyvbjerg, B. (2006) 'Five Misunderstandings about Case Study Research', Qualitative Inquiry, Vol. 12, No. 2, pp. 219-245.

Gløersen, E., Dubois, A., Copus, A. \& Schürmann, C. (2006) Northern Peripheral, Sparsely Populated Regions in the European Union \& Norway, Report 2006/2, Stockholm, Nordregio.

Hall Aitken (2007) Outer Hebrides Migration Study: Final Report, Report for Comhairle nan Eilean Siar (council), Stornoway, Western Isles Enterprise \& Communities Scotland.

Highlands \& Islands Enterprise (2009) Area Profiles: The Western Isles, Inverness, Highlands \& Islands Enterprise.

Instituto per la Ricerca Sociale (2011) Study on the Contribution of Local Development in Delivering Interventions Co-Financed by European Regional Development Fund in 2000-06 \& 2007-13: Final Report, Brussels, Study for DG Regional Policy of the European Commission.

Koenig, G. (2009) 'Realistic Evaluation and Case Studies: Stretching the Potential', Evaluation, Vol. 15, No. 1, pp. 9-30.

Martini, A. (2009) Making Impact Evaluations more 'Rigorous' through Use of Counterfactual Impact Evaluation Methods, European Commission, 6th Evaluation Conference, Warsaw, http://ec.europa.eu/regional policy/archive/conferences

Moncada, S, Camilleri, M., Formosa, S. \& Galea, R. (2010) 'From Incremental to Comprehensive: Towards Island-friendly European Union Policy-making, Island Studies Journal, Vol. 5, No. 1, pp. 61-68.

Monfort, P. (2009) Territories with Specific Geographical Features, Regional Policy Working Papers, No. 02/2009, DG Regional Policy, Brussels, European Commission.

Planistat Europe (2006) Analysis of Island Regions and Outermost Regions of the European Union, Report No. 2000.CE.0.AT.118, DG Regional Policy, Brussels, European Commission.

Samsø Energy Academy (2007) A Renewable Energy Island: Ten Years of Development, Samsø, Denmark Samsø Energy Academy.

Snedden Economics (2007) Outer Hebrides Tourism Update, Stornoway, Report for Highlands \& Islands Enterprise, VisitScotland(Outer Hebrides) \& Comhairle nan Eilean Siar.

Technopolis Group (2012), Evaluation of Innovation Activities: Methods and Practice, Study for DG Regional Policy of the European Commission, Brussels.

Yin, R.P. (1981) 'The Case Study Crisis: Some Answers', Administrative Science Quarterly, Vol. 26, No. 1, pp.58-65. 